\title{
Nomenclatural Notes on American Thymelaeaceae
}

\author{
Zachary S. Rogers \\ Missouri Botanical Garden, P.O. Box 299, St. Louis, Missouri 63116-0299, U.S.A. \\ zachary.rogers@mobot.org
}

Aвstract. The nomenclatural status of all published plant names applicable to American Thymelaeaceae at the rank of genus and below is evaluated. Thirtytwo of the 256 published names at specific and infraspecific ranks require effective typifications. Lectotypes are designated for 29 names: Daphne lagetto Sw., D. macrophylla Kunth, D. occidentalis Sw., D. pillopillo Gay, Daphnopsis bogotensis Meisn., D. brasiliensis Mart., D. caracasana Meisn., D. caribaea Griseb. var. ecuadorensis Domke, D. coriacea Taub., D. decidua Domke, D. ekmanii Domke, D. ericiflora Gilg \& Markgr., D. longifolia Taub., D. longipedunculata Gilg ex Domke, D. longiracemosa Gilg ex Domke, D. martii Meisn., D. purpusii Brandegee var. ehrenbergii Domke, D. racemosa Griseb., D. sessiliflora Griseb. ex Taub., D. zamorensis Domke, Goodallia guianensis Benth., G. guianensis var. parvifolia Benth., Lagetta funifera Mart. \& Zucc. (epitype also designated), Linostoma albifolium Barb. Rodr., Lophostoma bolleanum Domke, Schoenobiblus coriaceus Domke, S. daphnoides Mart., S. ellipticus Pilg., and S. peruvianus Standl. Neotypes are designated for three names: Daphnopsis crassifolia (Poir.) Meisn. var. eggersii Krug \& Urb., D. pseudosalix Domke, and D. selerorum Gilg.

Key words: Antilles Islands, Caribbean, Central America, Daphnopsis, Dirca, Drapetes, Falkland Islands, Funifera, Goodallia, Lagetta, Lasiadenia, Linodendron, Lophostoma, Neotropics, North America, Ovidia, Schoenobiblus, South America, Tepuianthus, the Americas, Thymelaeaceae.

Thymelaeaceae, now widely accepted as one of the basal families of Malvales, are composed of ca. 45 genera and 800 species that are mostly confined to Africa, Australia, and Asia (Herber, 2003). Two subfamilies are currently recognized for the family, the cosmopolitan Thymelaeaoideae (ca. 42 genera, 750 species) and the much smaller and mostly paleotropical Octolepidoideae (eight genera, ca. 50 species). In the Americas, the family is represented by 12 genera and ca. 115 species (or 14\% of the family total) that are distributed from southeastern Canada through southern Chile and Argentina, and also in the Falkland Islands and the Caribbean. All American genera except Tepuianthus Maguire \& Steyerm. belong to the much larger Thymelaeaoideae subfamily. Centers of species diversity are located in Brazil (particularly around Rio de Janeiro), northwestern South America (especially Ecuador, Colombia, and Venezuela), and the Greater Antilles. Despite the availability of relatively recent taxonomic treatments for some American genera, much of the nomenclature and typification of these groups has not been comprehensively evaluated, a shortcoming that is the primary focus of the research presented here.

\section{Taxonomic History of American Thymelaeaceae}

Daphnopsis Mart., with approximately 73 dioecious species, is by far the largest genus in the Americas, ranging from central Mexico to Chile and Argentina, and also throughout most of the Antilles. Nevling (1959) recognized 46 species in the last taxonomic revision of the genus and shortly afterward published a few corrections and updates, in which a few additional taxa were recognized (Nevling, 1960, 1963b). While most of Nevling's underlying taxonomy of Daphnopsis is reasonable, his treatment is difficult to use for identification purposes, because both staminate and pistillate flowers are required for the key (herbarium material is usually collected in fruit), and the species illustrations he provided only consisted of longitudinal floral dissections (about half of the species were only known to him from either staminate or pistillate specimens). Over the past 50 years, an additional 22 species from Central and South America and the Caribbean have been described (e.g., Cuatrecasas, 1962; Borhidi \& Muñiz, 1976; Nevling \& Barringer, 1986; Barringer \& Pruski, 2005), which has further increased the need for a comprehensive taxonomic reevaluation of Daphnopsis.

The second largest American genus, Schoenobiblus Mart. (ca. 10 species), also dioecious, occurs predominately in lowland tropical South America, with a single species, S. grandifolia Urb., endemic to Trinidad and Tobago. Schoenobiblus has never been taxonomically revised. Most recent attention paid to the genus has been the description of a few taxonomic novelties (Barringer \& Nevling, 1987; Steyermark, 1987) and the occasional treatment of one or two taxa in regional floras and catalogs published for Peru 
(Macbride, 1941; Zarucchi, 1993), Trinidad and Tobago (Philcox, 1978), Ecuador (León-Yánez, 1999), French Guiana (Kawasaki \& Mori, 2002), and Venezuela (Rogers et al., 2005).

Maguire and Steyermark (1981) described the enigmatic Tepuianthus (six species, Venezuela, adjacent Colombia, and Brazil; Steyermark, 1986-1987) in its own family and ascribed it to Sapindales (sensu Cronquist, 1968). Molecular data, well supported by morphology, suggest that Tepuianthus is sister to the basal subfamily Octolepidoideae within the Thymelaeaceae (Horn, 2004), and Wurdack and Horn (2001) recommended that the genus be placed in its own subfamily, a view that is shared by the author of the present paper. All seven of the published Tepuianthus names (six specific and one varietal; Berry \& Rogers, 2005) do not pose nomenclatural or typification problems and are therefore not further discussed here.

Of the remaining 10 American genera in the family, none are composed of more than four species, and each genus has been taxonomically evaluated at least once since the 1960s. Nevling published comprehensive revisions for Lophostoma (Meisn.) Meisn. (four species, Amazonian Brazil and Amazonas, Venezuela; Nevling, 1963a), Ovidia Meisn. (three species, Bolivia, Chile, nearby Argentina; Nevling, 1964; Rogers et al., 2004), and Funifera Leandro ex C. A. Mey. (four species, Brazil; Nevling, 1965, 1976). Nesom and Mayfield (1995) described a third narrow endemic species in the North American genus Dirca L., based on material collected from northeastern Mexico, and more recently, Floden et al. (2009) described a fourth species endemic to Kansas, Arkansas, and probably Missouri. Two genera, Linodendron Griseb. (three Cuban species) and Lagetta Juss. (three species, Cuba, Jamaica, Haiti, Dominican Republic), were both treated by Noa Monzón (1992, 2009). Plowman and Nevling (1986) recognized two species of Lasiadenia Benth. (Venezuela, Colombia, Brazil), and an identification key for the genus was provided in Rogers et al. (2005). Heads (1990) recircumscribed Drapetes Banks ex Lam. to include a single species, D. muscosus Lam., from southern Chile, Argentina, and the Falkland Islands. The monotypic Goodallia Benth. is distributed in the lowlands of Guyana and Roraima, Brazil, and remains poorly known (Rossi, 1997, unpublished; Berry et al., 2007).

\section{Materials and Methods}

A list of American plant names of Thymelaeaceae was compiled based on thorough searches of pertinent botanical literature, herbarium specimen annotations, and online databases of plant nomenclatural data.
Relevant specimens and literature at BM, F, G, K, MO, NY, P, and US were personally inventoried, photographed, scanned, and databased. Additional types and original material were examined and cataloged from several sources including online digital image repositories and databases, type photograph collections, and specimen images available on microfiche. Specimens were consulted from 33 herbaria: A, B, BM, BREM, C, CAS, CORD, E, F, G, GH, GOET, HBG, K, L, LE, M, MEL, MO, NY, P, PI, R, RB, S, SP, SPF, TRIN, U, UC, US, W, and Z. Curator R. Vogt (Botanischer Garten und Botanisches Museum Berlin-Dahlem) searched for extant original material of every name typified in this paper that was based on material deposited in the B herbarium, but found that the types for all names were destroyed during the Second World War.

Typification methodology followed Turland and Jarvis (1997), McNeill et al. (2006), and Rogers and Spencer (2006). When selecting types, the most complete herbarium specimens were chosen over illustrations whenever possible. Handwritten inscriptions on herbarium material were compared to handwriting examples taken from several sources including Steinberg (1977), ABG (2010), the Swedish Museum of Natural History (2010), and the personal correspondence of authors.

\section{Results and Discussion}

A total of 256 names belonging to American Thymelaeaceae at the rank of genus and below were identified: 23 generic, 207 specific, and 26 infraspecific (11 subspecies and 15 varieties). In all, 215 names $(84 \%)$ were validly published, 17 were invalid, and 24 were valid but illegitimate (for details see Tropicos, 2010).

\section{NAMES PUBLISHED AT THE GENERIC RANK}

Of the 23 generic names, 19 are valid and are already effectively typified, while the other four are invalid orthographic variants (for details see Tropicos, 2010). Three names are illegitimate: Dofia Adans. (Adanson, 1763) [三 Dirca], Nordmannia Fisch. \& C. A. Mey. (Meyer, 1843) [= Daphnopsis $]$ non Ledeb. ex Nordm. (Nordmann, 1837), and Goodallia Benth. (Bentham, 1845) non T. E. Bowdich (Bowdich, 1825). Names published at the rank of genus were typified by reference to a single species name in their original publications (Art. 37.3, McNeill et al., 2006), with two exceptions. Typifications were published retroactively by Lamarck (1792: 373) when he described Lagetta lintearia Lam. as the first constituent species of Lagetta (Jussieu, 1789), and by 
Nevling (1959: 271) when he designated Gastrilia umbellata Raf. (Rafinesque, 1838), nom. illeg. (Daphne occidentalis Sw., typified here) [= Daphnopsis occidentalis ( $\mathrm{Sw}_{w}$ ) Krug \& Urb.] as the type for Gastrilia Raf.

The genus Bosca Vell. (Vellozo, 1825) was validly published with a single species (Bosca stupacea Vell.), but the whereabouts of the source specimens are unknown (Stafleu \& Cowan, 1986) and the brief protologue description and associated illustration (Vellozo, 1827) lack sufficient detail for definite ascription to Thymelaeaceae. Meisner (1857) treated Bosca as a synonym of Daphnopsis, and Nevling (1959) further suggested that B. stupacea represented a species within his own Daphnopsis subg. Neivira (Griseb.) Nevling.

\section{NAMES PUBLISHED AT SPECIFIC AND INFRASPECIFIC RANKS}

Of the 233 names published at the rank of species and below, 172 were published for new taxa, 50 were recombinations, and 11 names were avowed substitutes. Nineteen names are illegitimate, while 15 names, including three orthographic variants, are invalid (for details see Tropicos, 2010).

\section{TYPIFICATION OF SPECIFIC AND INFRASPECIFIC NAMES}

About 80 of the 138 legitimate names published as new taxa were effectively typified within their original publications (counts exclude recombinations and avowed substitutes). Twenty-seven additional names were effectively typified by subsequent authors, although the lectotypification of Linostoma calophylloides Meisn. [ $\equiv$ Lophostoma calophylloides (Meisn.) Meisn.] by Nevling (1963a: 157-158) is supersedable according to Article 9.17 (McNeill et al., 2006) because the holotype, Spruce 967 (M 0145930), is still extant in the Munich herbarium.

Thirty-two names (28 specific and four varietal) are typified in the following list. Complete synonymy for the American taxa is not provided here, but nomenclatural and taxonomic synonyms for all names are available on the searchable Tropicos database (Tropicos, 2010).

\section{DAPHNOPSIS}

Daphnopsis americana (Mill.) J. R. Johnst., Proc. Boston Soc. Nat. Hist. 34(7): 242. [25 June] 1909 [also Contr. Gray Herb. 37: 242. (25 June) 1909]. Basionym: Laurus americana Mill., Gard. Dict. (ed. 8): Laurus no. 10. [16 Apr.] 1768. TYPE: Mexico. Veracruz, 1730, W. Houstoun s.n. (holotype, BM 000645493).

Daphnopsis americana subsp. americana.
Daphnopsis americana subsp. ecuadorensis (Domke) Nevling, Ann. Missouri Bot. Gard. 46: 315. 1959 [28 Jan. 1960], as "ecuadoriensis." Basionym: Daphnopsis caribaea Griseb. var. ecuadorensis Domke, Notizbl. Bot. Gart. BerlinDahlem 12: 727. [6 Dec.] 1935. TYPE: Ecuador. Balao, 27 Feb. 1892, H. F. A. von Eggers 14316 (lectotype, designated here, Z 000027994; possible isotypes, A 00061503, LE, M 0145984, US 00117223).

Domke's holotype of Eggers 14316 at B was destroyed. Sheet Z 000027994 is designated as the lectotype of Daphnopsis caribaea var. ecuadorensis, because it includes a typewritten Ex Museo botanico Berolinensi label and the month of February as mentioned in the protologue (Domke, 1935: 727). The duplicates of Eggers 14316 at A, LE, M, and US are cited as possible isotypes since March is written on the labels. None of the examined material was annotated by Domke. In the last revision of the genus, Nevling (1959) formally recognized D. americana subsp. ecuadorensis and five other subspecies besides the autonym. León-Yánez (1999) reduced the Ecuadorian subspecies to synonymy with the species, although Nevling reported that the Ecuadorian material showed distinct morphological differences related to pedicel length and pistillode pubescence, and that those differences were correlated with an allopatric geographic distribution. The subspecies is tentatively retained here, but a comprehensive reevaluation of $D$. americana is needed to ascertain the taxonomic limits of the species and Nevling's subspecific taxa.

Daphnopsis brasiliensis Mart., Nov. Gen. Sp. Pl. 1: 65. [1 Oct.] 1824. TYPE: Brazil. São Paulo: "in Morro do Lobo prov. S. Pauli," s.d., C. F. P. von Martius s.n. (lectotype, designated here, M 0145988).

Daphnopsis and its type, D. brasiliensis, were validly published simultaneously via a single description (descriptio generico-specifica) in accordance with Article 42.1 (McNeill et al., 2006). In the protologue (Martius \& Zuccarini, 1824b: 65), Martius used specimens taken from multiple plants to briefly describe staminate and pistillate flowers and fruits, and he cited the provenance of the original material as "Habitat in umbrosis sylvaticis ad Morro do Lobo atque inter Villam de S. João de Atibaya atque Jacaray, Provinciae S. Pauli versus confinia Provinciae Minas Geraës." There are four sheets at M (0145986-0145989) that correspond to the collections cited in the protologue. Among these syntypes, sheet 
M 0145988 is designated as the lectotype of $D$. brasiliensis because it bears handwritten inscriptions by Martius of the species name and one of the place names (Morro do Lobo) specifically mentioned in the original publication. The specimen label on sheet M 0145987 notes the same locality as the lectotype, but the specimens affixed to the sheet were probably collected from a different plant. Contendas, a locality not explicitly mentioned in the protologue, is noted on the labels of the syntypes, M 0145986 and M 0145989.

Daphnopsis caracasana Meisn., Prodr. 14(2): 521522. [Nov.] 1857. TYPE: Colombia. 1846, $H$. Karsten 211 (lectotype, designated here, G-DC 00130580; isotypes, G 00190835, G 00190836, NY 00386261 fragm., P 00713261).

Daphnopsis bogotensis Meisn., Prodr. 14(2): 521. [Nov.] 1857. TYPE: Colombia. [Betw. Bogotá \& Zipaquira], Prov. Quito Perou, 1843, K. Hartweg 1366 (lectotype, designated here, G 00190832; possible isotypes, BM, G 00190833, G 00190834, K 000567838, K 000567839, LE [specimen at right], NY 00386260 fragm., P 00713256, P 00713288, P 00713289, W not seen).

Regarding Daphnopsis caracasana, Meisner (1857: 521-522) mentioned at least two different sources of original material in the protologue as "In Colombiâ (Karsten n. 211!). Daphne Caracasana Klotzsch! mss. in herb. DC., ect. ... (v.s. in herb. DC. et Shuttl.)." The cited Shuttleworth syntype material was not found at BM despite a thorough search of their entire Thymelaeaceae collection. Sheet G-DC 00130580 of the Karsten 211 collection is designated as the lectotype of $D$. caracasana because the collection number and depository is clearly referenced in the protologue. Neither the sheet in G-DC nor the two sheets in the general $G$ herbarium bear Meisner's handwritten annotation of the species name.

In the protologue of Daphnopsis bogotensis, Meisner (1857: 521) provided the provenance statement "In Colombiâ, inter urbem Bogota et Zipaquira (Hartweg, n. 1366!), et? prope Santa-Marta (Purdie, cfr. D. Purdiei). Thymelaea Benth.! pl. Hartweg. p. 247 ... (v. s. in herb. Boiss.)," indicating that at least two, and possibly even three, sources of original material were used for the description. No material of the species attributable to Purdie was found, and it is plausible that Meisner's mention of that collection was based on the description and locality statements published in the earlier Plantas Hartwegianus (Bentham, 1846: 247). Several duplicates of Hartweg 1366 were examined from BM, G, K, LE, NY, and P. One of the three sheets seen at $\mathrm{G}(00190832)$ was annotated with the species name by Meisner, and it alone is designated as the lectotype of $D$. bogotensis. The other examined sheets are all regarded as possible duplicates of the lectotype.

Daphnopsis coriacea Taub., Bot. Jahrb. Syst. 12 (Beibl. 27): 7. [24 June] 1890. TYPE: Brazil. Rio de Janeiro, sommet da Tinguá, 6 June 1877, A. F. M. Glaziou 8911 (lectotype, designated here, $\mathrm{P}$ 00713293; isotypes, C, F fragm. not seen, G 00190831 [2], K 000567848, K 000567849 , NY, P 00713292, RB 183448).

Taubert (1890) mentioned two syntypes without a specific Brazilian locality and date in the protologue of Daphnopsis coriacea (Glaziou 8911 and 14226). Nevling (1959: 341, 343; 1968: 18) cited Glaziou 8911 as the type collection, but his statements do not represent an effective lectotypification because he indicated four different depositories (C, F, NY, P) for the collection instead of selecting a single specimen in one herbarium, thereby conflicting with Article 8.1 (McNeill et al., 2006). Taubert's main herbarium at B was lost (Stafleu \& Cowan, 1986). Examined duplicates of Glaziou 8911 more closely match the protologue description compared to those of Glaziou 14226, especially with respect to the rounded-obtuse apices of the leaf blades. Sheet P 00713293 of Glaziou 8911 bears a typewritten P label with collection information in anonymous handwriting along with a second label including the collection locality and date in Glaziou's handwriting. This sheet is designated as the lectotype of D. coriacea. The second $\mathrm{P}$ sheet (00713292) and the other examined sheets are regarded as duplicates of the lectotype. None of the studied sheets were annotated by Taubert.

Daphnopsis crassifolia (Poir.) Meisn., Prodr. 14(2): 524. [Nov.] 1857. Basionym: Daphne crassifolia Poir., Encycl. Suppl. 3: 316. [24 Sep.] 1813. TYPE: [Haiti or Dominican Republic.] St. Domingue, s.d., H. Nectoux s.n. (holotype, FI not seen; isotype, P 00713315).

Daphnopsis crassifolia (Poir.) Meisn. var. eggersii Krug \& Urb., Bot. Jahrb. Syst. 15: 350. [10 Jan.] 1892. TYPE: Dominican Republic. Pedernales, Sierra de Bahoruco, secc. Los Arroyos, 1500 m, 10 July 2007, T. Clase, L. Raz, D. Castillo, L. Reinoso \& E. Soto 4545 (neotype, designated here, MO 6061840; isotype, NY 1163671).

Urban (1892: 350) cited the original material in the protologue of Daphnopsis crassifolia var. eggersii as "Habitat in Sto. Domingo in sylvis infra Valle nuevo alt. 1900 m. m. Majo fructif.: Eggers n. 2317." The holotype at B was destroyed and no extant duplicates 
of Eggers 2317 have been found. Clase et al. 4545 (MO 6061840), designated here as the neotype of the variety, matches the Latin description and was collected ca. 125 air-km west-southwest of the type locality of the destroyed Eggers 2317 collection. Daphnopsis crassifolia var. eggersii was most recently treated as a synonym of $D$. crassifolia by Liogier (1982), following Nevling (1959). That synonymy is provisionally followed here, but there is a sizeable amount of variation in the studied material and further examination may suggest that the variety should be recognized as a distinct species.

Daphnopsis ekmanii Domke, Repert. Spec. Nov. Regni Veg. 32: 85. [1 Mar.] 1933. TYPE: Dominican Republic. Samaná: Laguna, Loma Zaramagua, ca. 250 m, 9 June 1930, E. L. Ekman H15259 (lectotype, designated here, S 04-787; isotypes, G 00190942, K 000567860, NY 00084367, S 04-786, US 00117226).

Daphnopsis ekmanii was based on one sterile collection (E. L. Ekman H15259) and the B holotype was destroyed. Of the examined duplicates $(\mathrm{G}, \mathrm{K}, \mathrm{NY}, \mathrm{S}$, US), Domke personally annotated both $\mathrm{S}$ sheets and the K sheet as types on 24 November 1932 . The $S$ sheet with the most complete label data (S 04-787) is designated as lectotype. Daphnopsis ekmanii was treated as a species of undetermined status by Nevling (1959), but was later recognized as a distinct species by Liogier (1982). The species may still only be known from its type. Type material of D. ekmanii has leaves most similar to those found on the type of the Puerto Rican species, $D$. helleriana Urb., except for a more narrowly obovate leaf blade with an acute or even acuminate apex. The broader blades of $D$. helleriana, by contrast, have a more rounded or obtuse apex. Daphnopsis ekmanii is recognized here following Liogier (1982) pending further investigation with additional collections.

Daphnopsis fasciculata (Meisn.) Nevling, J. Arnold Arbor. 44(3): 404. [9 July] 1963. Basionym: Funifera fasciculata Meisn., Fl. Bras. 5(1): 68. [1 Jan.] 1855. TYPE: Brazil. "habitat in prov. Minas Geraës," J. F. Widgren 1025 (holotype, MEL 2123977; isotype, NY fragm. 00017524).

Daphnopsis longifolia Taub., Bot. Jahrb. Syst. 12 (Beibl. 27): 9. [24 June] 1890. TYPE: Brazil. Rio de Janeiro, campos da Bocaina, du Sobrado, 8 Jan. 1876, A. F. M. Glaziou 8252 (lectotype, designated here, C; possible isotypes, K 000567844, P 00713307, P 00713308, RB 44892, US 00117230).

Taubert (1890) mentioned two collections in the protologue of Daphnopsis longifolia, Glaziou 8252, with staminate flowers, and Glaziou 12141, with pistillate flowers. Nevling (1959: 344, 346) later cited Glaziou 8252 as the type and listed duplicates at C, F, $\mathrm{P}, \mathrm{RB}$, and US. His statement cannot represent an effective typification, since a single specimen in one herbarium was not mentioned (Art. 8.1, McNeill et al., 2006). Taubert's main herbarium at $B$ was lost (Stafleu \& Cowan, 1986). The examined C sheet (no barcode/ accession number) bears label information cited in the protologue and includes four leafless branches and about eight leaves taped down to the sheet. All of these specimens together are designated as the lectotype of $D$. longifolia. None of the examined sheets bear Taubert's handwriting.

Daphnopsis longipedunculata Gilg ex Domke, Notizbl. Bot. Gart. Berlin-Dahlem 12: 723-724. [6 Dec.] 1935. TYPE: [Venezuela. Bolívar: Valley of the Cuquenan.] Roraima, im Galeriewald, bei dem Dorfe, 1400 m, Dec. 1909, E. Ule 8739 (lectotype, designated here, K 000035671 [@ fls.]).

Domke (1935) cited two collections in the protologue of Daphnopsis longipedunculata, Ule 8739, from a pistillate individual (flowers and immature fruits), and Schomburgk 1057, from a staminate individual. The syntypes at B were destroyed, and no extant duplicates of Schomburgk 1057 have been located. A duplicate of Ule 8739 with an ample pistillate specimen that closely matches the original description was found at $\mathrm{K}$ (K 000035671). That sheet is designated here as lectotype. The label on the lectotype lacks the country of collection and annotations by Gilg and Domke, but Roraima is specifically mentioned. Although Domke (1935) attributed Ule 8739 to Roraima, Brazil, in the protologue, Ule (1914: 47) had previously referred to $D$. longipedunculata in his description of the Roraima vegetation while discussing the Valley of the Cuquenan, which is located in present-day Bolívar, Venezuela. Only two other collections of the species have been examined; both were likewise collected from Bolívar (Dezzeo \& Hernandez 121, 136, MO).

Daphnopsis macrophylla (Kunth) Gilg, Nat. Pflanzenfam. 3(6a): 236. [10 July] 1894. Basionym: Daphne macrophylla Kunth, Nov. Gen. Sp. (quarto ed.) 2: 151. [8 Dec.] 1817. Daphne laurifolia Willd. ex Kunth, Syn. Pl. 1: 446. [9 Dec.] 1822, nom. inval., pro Daphne macrophylla Kunth. TYPE: [Ecuador.] "Crescit in radicibus montis ignivomi Tunguraguae inter Ganse et Rio Puela, alt. 1240 hex. (Regno Quitensi.) Floret Julio," F. W. H. A. von Humboldt \& A. J. A. 
Bonpland s.n. (lectotype, designated here, $\mathrm{P}[\mathrm{Hb}$. Humboldt \& Bonpland, fr. sheet]; probable isotypes, P [Hb. Humboldt \& Bonpland, fl. sheet], B-Willd. [3209], NY 00386250 fragm. [3209 \& 7550], P 00713287 [3209]).

Daphne lancifolia Humb. [\& Bonpl.] ex Wikstr., Diss. Daphne 53. [13 June] 1817. Daphnopsis humboldtii Meisn., Prodr. 14(2): 520. [Nov.] 1857, nom. illeg. TYPE: Peru. F. W. H. A. von Humboldt [\& A. J. A. Bonpland] 3209 (holotype, B-W 07550 in B-Willd.; probable isotypes, P [Hb. Humboldt \& Bonpland, fr. sheet], P [Hb. Humboldt \& Bonpland, fl. sheet], NY 00386250 fragm. [also numbered 7550], P 00713287).

Daphne macrophylla Kunth and D. lancifolia Humb. [\& Bonpl.] ex Wikstr., two validly published names, represent the same American species currently recognized as Daphnopsis macrophylla (Kunth) Gilg. In regard to which name has priority, the name and description of Daphne lancifolia originally appeared in Wikström's dissertation entitled Dissertatio de Daphne with a title page date of 13 June 1817 (Wikström, 1817a). According to Stafleu and Cowan (1988: 284), the dissertation was also published as a "commercial edition" with a slightly different title page (Wikström, 1817b) sometime during 1817. Three years later, the name and description were republished almost verbatim in a second updated edition of the dissertation (Wikström, 1820), with the only notable change between the editions being the addition of Bonpland as a secondary author and collector of the original material (the names and specimens were originally attributed solely to Humboldt). Daphne lancifolia was never adopted post1820 , presumably because the commercial edition of Wikström's Dissertatio was always regarded as the validating publication. Post-1820, Daphne lancifolia was treated first as a synonym of Daphne macrophylla (Kunth, 1822), before being replaced along with Daphne macrophylla by the illegitimate Daphnopsis humboldtii Meisn. (Meisner, 1857), and has most recently been reduced to synonymy with Daphnopsis macrophylla (Kunth) Gilg (e.g., Nevling, 1959; LeónYánez, 1999). Kunth's Daphne macrophylla was effectively published on 8 December 1817 according to Stafleu and Cowan (1979, TL-2 entry no. 3143), and if we accept the date on the title page of Wikström's original dissertation (Wikström, 1817a) as the date of effective publication for Daphne lancifolia, the name would have priority over Kunth's name by nearly six months. Given this possible scenario, a conservation proposal for Daphne macrophylla was considered, but in the end abandoned, because Kunth's basionym and Gilg's subsequent recombination are already well established in the literature and herbarium. Furthermore, resurrecting Daphne lancifolia would require a new combination in Daphnopsis for a species with a relatively narrow distribution in Andean Ecuador, not to mention that the actual orthography of the name itself is in question because the epithet was spelled "lancifolia" in Wikström's dissertation (1817a, b, 1820), but was written as "laurifolia" on the original material deposited in the Willdenow herbarium at B (Humboldt 3209, B-W 07550). The specimens on that sheet, which were collected by Humboldt and Bonpland, are together regarded as the holotype of Daphne lancifolia.

Regarding the typification of Daphne macrophylla, Kunth (1817) described flowering and fruiting material from Ecuador in the protologue and did not cite a specimen. There are two unnumbered sheets, one with flowers and the other with fruits, deposited in the Herbier Humboldt \& Bonpland at P that correspond to the name. Kunth personally annotated the sheet with large leaves and fruits, and the leaves on that sheet more closely match the leaf description given in the protologue. All parts on that sheet are collectively designated as lectotype of $D$. macrophylla. The second sheet in the Herbier Humboldt \& Bonpland with flowers and smaller leaves, and the other examined sheets in B-Willd., NY, and P are probably either duplicates of the lectotype or syntypes of $D$. macrophylla. At least some of the original material and examined duplicates of both $D$. macrophylla and $D$. lancifolia may have come from the same plant or from the same set of plants originally collected by Humboldt and Bonpland.

Daphnopsis martii Meisn. in Mart., Fl. Bras. 5(1): 66, pl. 28, f. 2. [1 Jan.] 1855. TYPE: Brazil. Rio de Janeiro, habitat in sylvis, Nov. 1817, C. F. P. von Martius 119 (lectotype, designated here, M 0145993; isotype, M 0145994).

The protologue of Daphnopsis martii (Meisner, 1855: 66) included a detailed description of staminate material, a few floral illustrations, and the provenance statement "Sched. n. 119. Martii, monentis Anibam Aubl. conferendam esse. Habitat in silvis montis Corcovado, prov. Rio de Janeiro, flor. m. Aug. Sept.: M." There are three relevant sheets in the Munich herbarium (M 0145993-0145995), none of which bear the handwritten annotation of the species name by Meisner or Martius. Labels on sheets M 0145993 and M 0145994 are numbered 119 and dated Nov. 1817. Rio de Janeiro is mentioned on both sheets, but only sheet M 0145994 includes the more detailed Corcovado locality cited in the protologue. The reference to November on both labels is ambiguous as only the months of August and September were provided in the protologue. Sheet M 0145995 lacks a number and date, but includes attribution to Rio de 
Janeiro and Corcovado. It is impossible to determine if Meisner used all three sheets in his description, and whether or not these specimens came from the same locality and gathering. Given this ambiguity, Martius 119 (M 0145993) is designated as the lectotype of $D$. martii because it is in the best physical condition. Since sheet M 0145994 is numbered 119, it is regarded as a duplicate of the lectotype, whereas the unnumbered and undated sheet M 0145995 is instead treated as a syntype. No intact open flowers remain on the three M sheets, so the detailed floral illustrations provided in the protologue should be used in conjunction with the type specimens.

Laclette (1977: 11) failed to designate a holotype when publishing the name "Daphnopsis aemygdioi" and instead cited two syntypes (Laclette 45 [R 12882] and Laclette 46 [R 12883]), which invalidates the name according to Article 37.1 (McNeill et al., 2006). Laclette contrasted the invalid name with Daphnopsis utilis Warm., names that were both based on material collected around Rio de Janeiro, but Rossi (1997, unpublished) provided compelling morphological evidence that Laclette's "Daphnopsis aemygdioi" is synonymous with D. martii.

Daphnopsis occidentalis (Sw.) Krug \& Urb., Bot. Jahrb. Syst. 15: 349. [10 Jan.] 1892. Basionym: Daphne occidentalis Sw., Prodr. (Swartz) 63. [20 June-29 July] 1788. TYPE: Jamaica, s.d., Herb. O. Swartz s.n. (lectotype, designated here, S S-R1401; probable isotype, S S-R-1402).

Two sheets of original material for Daphne occidentalis were examined from S (S-R-1401 and SR-1402). Comparing the two, sheet S-R-1401 (ex Herb. Swartz) includes the most complete, fertile specimens and is the only one annotated with the species name by Swartz. That sheet alone is designated as lectotype. Sheet S-R-1402 (ex Herb. Swartz, ex Herb. Osbeckii on verso) was not annotated by Swartz, but is probably a duplicate of the lectotype. Several other Swartz specimens belonging to the species were examined at BM, C, and G-DC. Some or all of these may be duplicates of the lectotype or syntype material.

Daphnopsis pseudosalix Domke, Notizbl. Bot. Gart. Berlin-Dahlem 12: 724-725. [6 Dec.] 1935. TYPE: Brazil. Santa Catarina, 1816-1821, A. Saint-Hilaire 1749 (neotype, designated here, P 00713798; isotypes, P 00713799, P 00713800).

Domke (1935) cited a single staminate collection (C. Pabst 546) from Santa Catarina in the protologue of Daphnopsis pseudosalix. The type material at B was destroyed and no extant duplicates were found. SaintHilaire 1749 (P 00713798) includes a Santa Catarina label and four staminate specimens that all match the protologue description. The entire sheet is designated as neotype. Two other sheets of Saint-Hilaire 1749 were found at P (P 00713799, P 00713800), and the staminate specimens affixed to those sheets are regarded as duplicates of the lectotype. The illustrations of $D$. pseudosalix and the description of pistillate flowers provided in Nevling (1963b) should be disregarded, as that information was based on a misidentified collection (E. Ule 504, HBG). For illustrations of both staminate and pistillate flowering material and a complete description of the species, see Nevling and Raulino Reitz (1968).

Daphnopsis purpusii Brandegee, Univ. Calif. Publ. Bot. 4(3): 89. [26 May] 1910. TYPE: Mexico. Puebla: Cerro de Paxtle, Sep. 1909, C. A. Purpus 4116 (holotype, UC 136842; isotypes, A not seen, BM, E 00313901, F 276623, G 00190932, MEXU not seen, MO 3942641, NY 00386257, US 00117239).

Daphnopsis purpusii Brandegee var. ehrenbergii Domke, Notizbl. Bot. Gart. Berlin-Dahlem 12: 728. [6 Dec.] 1935. TYPE: Mexico. Puebla: Tehuacan?, Sep. 1911, C. A. Purpus 5707 (lectotype, designated here, F 299257; isotypes, A not seen, BM not seen, GH 00257836, MO 5467671, NY 1104559, US not seen).

Daphnopsis decidua Domke, Notizbl. Bot. Gart. BerlinDahlem 12: 726-727. [6 Dec.] 1935. TYPE: Mexico. Puebla: Tehuacan, [El Riego,] July 1906, C. A. Purpus 4447 (lectotype, designated here, US 00117225; isotypes, A not seen, F 344055, GH 00061456, MO 5467672).

Domke (1935: 728) cited two Mexican collections in the protologue of Daphnopsis purpusii var. ehrenbergii as "bei Los Baños. Ein 2-3 m hohes Baümchen. (Mit Früchten im Dezember 1838-Ehrenberg n. 1012 [Typus!].-Bei Puebla im September 1911 steril-Purpus n. 5707.)." No holotype material of Ehrenberg 1012 was found at B, but extant duplicates of the Purpus 5707 paratype were examined at F, GH, MO, and NY. Sheet F 299257 of Domke's paratype still has one attached fruit and is designated as the lectotype of $D$. purpusii var. ehrenbergii in accordance with Article 9.10 (McNeill et al., 2006). The other examined duplicates of the lectotype are pistillate with loose fruits. There is a staminate flowering specimen labeled Purpus 5707 in the Paris herbarium (P 00761269) that is probably not a duplicate of the original material, because flowers were not described in the protologue and the date of June 1912 written on the label disagrees with the protologue date of September 1911. 
Domke mentioned that fruits of Daphnopsis purpusii var. ehrenbergii are larger than those of $D$. purpusii (7 $\mathrm{mm}$ vs. $4 \mathrm{~mm}$ in diameter, respectively), but his observation may have been based on incomplete fruiting material because the fruits of several examined isotypes of D. purpusii (Purpus 4116) measure 6-7 $\mathrm{mm}$ in diameter. Nevling (1959) noted that the species could be divided into two groups based on indument (pubescent in typical D. purpusii vs. glabrous in $D$. purpusii var. ehrenbergii). According to Nevling, the variation did not warrant recognition of two separate taxa because the flowers were so similar, and his view is tentatively followed here.

In the protologue of Daphnopsis decidua, Domke (1935) cited two different Mexican collections from El Riego (Tehuacán, Puebla), noting Purpus $4447^{\prime}$ from June 1912 as the type, and Purpus 4447 from July 1906 as the isotype. The original material of both collections at B was destroyed. Four extant duplicates of Purpus 4447 were examined (F, GH, MO, US), and each one bears the original determination ("Daphnopsis salicifolia Meisner, form?") in anonymous handwriting that was explicitly mentioned in Domke's protologue. Puebla and Tehuacan are noted on the labels, but the more specific locality of "El Riego" is not included. The specimen on the US sheet is in the best physical condition of the examined duplicates and is designated as the lectotype of $D$. decidua.

Daphnopsis racemosa Griseb., Symb. Fl. Argent. 134. [Mar.-Apr.] 1879 [also Abh. Königl. Ges. Wiss. Göttingen 24: 134. 1879]. TYPE: Argentina. Concepción del Uruguay, Ufergebüsch am Puerto de las Piedras, 12 Oct. 1875 (ф fls., imm. fr.), P. Lorentz 205 (lectotype, designated here, GOET 003307; isotype, CORD [as Lorentz 205ß]).

Daphnopsis longiracemosa Gilg ex Domke, Notizbl. Bot. Gart. Berlin-Dahlem 12: 728-729. [6 Dec.] 1935. TYPE: Brazil. Ceará: Pico Alto, Serra de Baturité, Sep. 1910 († fls.), E. Ule 9077 (lectotype, designated here, K 000567853).

In the protologue of Daphnopsis racemosa, Grisebach (1879: 134) cited the provenance "E. [Entre Ríos]: in fruticetis ripariis pr. Concepcion de Uruguay," and described staminate and pistillate flowers and fruits, indicating that he used at least two different collections in the description. Hunziker (1960: 352) discussed three different Lorentz collections at CORD as "Isocótypos?" of D. racemosa, none of which bears annotations by Grisebach: Lorentz $205[\alpha]$ (30 Oct. 1875, fruits), 205[ $\beta]$ (12 Oct. 1875, pistillate flowers and immature fruits), and 1159 (Oct. 1877, staminate flowers). Hunziker added his own alpha and beta designations after Lorentz 205 on the herbarium labels to indicate that the specimens came from different localities and gathering events. Two years later, Hunziker traveled to Universität Göttingen, the home institution of Grisebach and Lorentz, to study the original Lorentz collections and to update his 1960 publication with GOET material (Hunziker, unpublished; G. Barboza, pers. comm.). In his updated manuscript, which was never published, he noted on 19 March 1962 that duplicate material of Lorentz $205[\alpha]$ and 205[ $\beta]$ (CORD) was at GOET. Both of those sheets (GOET 003307, 003308) were annotated by Grisebach and lack Hunziker's alpha and beta designations. Sheet GOET 003307 was dated 12 Oct. 1875 and bears pistillate flowers and immature fruits, whereas sheet GOET 003308 was dated 30 Oct. 1875 and bears either mature or nearly mature fruits. A slightly more complete specimen is affixed to Lorentz 205 (GOET 003307), so the entire sheet is designated as the lectotype of D. racemosa. Sheet G 003308, dated a few weeks later than the lectotype collection, is a syntype. The CORD sheet that was annotated by Hunziker as Lorentz 205 $\beta$ is regarded as a duplicate of the lectotype. Besides the sheet of Lorentz 1159 at CORD that could be syntype material, several other Lorentz collections belonging to $D$. racemosa have been examined at G, GH, K, M, MO, and US. These sheets are variously numbered and dated, with some totally lacking collection number and date information. It is impossible to identify which of these examined specimens could be duplicates of the original material, because none of them were annotated by Grisebach.

In the protologue of Daphnopsis longiracemosa, Domke (1935) described staminate and pistillate flowers, indicating that he used material from at least two different plants mixed under the same collection number (Ule 9077). The original material at $\mathrm{B}$ was destroyed. One duplicate at K (K 000567853) includes ample pistillate material and the entire sheet is designated as the lectotype of D. longiracemosa. Four sheets of Ule 9077 with staminate specimens were also examined (G 00190931 [2], U 0006865, US 00117231), and all of these are regarded as syntypes since they did not come from the same plant as the K lectotype. None of the examined specimens were annotated by Domke or Gilg, despite Domke's notation of "Gilg in sched." after the name in the protologue (Domke, 1935: 728).

Daphnopsis selerorum Gilg, Verh. Bot. Vereins Prov. Brandenburg 58: 153. [1 May] 1917. TYPE: Guatemala. Huehuetenango: betw. Xoxlac \& Nucapuxlac, Sierra de los Cuchumatanes, 
1650-2500 m, 17 July 1942 (ㅇ fls.), J. Steyermark 48933 (neotype, designated here, F 1131780).

Gilg (1917: 153), in the protologue of Daphnopsis selerorum, described pistillate material and cited the provenance of the original collection as "Habitat in Guatemala, in dept. Huehuetenango: in distr. Nenton, prope Yalambohoch, in silva primaeva humida: Seler n. 2866-Flor.: Aug." No extant duplicates of Seler 2866 have been found. Compared to Gilg's description, the pistillate neotype (Steyermark 48933, F 1131780) designated here has slightly larger leaves and longer pedicels, and was collected about 25 air$\mathrm{km}$ east of Seler's type locality. Nevling (1959) recognized D. selerorum as distinct from D. radiata Donn. Sm., and synonymized another Guatemalan species, D. malacophylla Standl. \& Steyerm., with D. selerorum. Standley and Williams (1962) instead considered $D$. selerorum to be a synonym of the earlier D. radiata, and resurrected D. malacophylla from Nevling's (1959) synonymy and treated it as a distinct species. Standley and Williams (1962: 238, fig. 38) also used Steyermark 48933 for their illustration of $D$. radiata. Regarding $D$. radiata, the protologue description (Donnell Smith, 1889) and holotype (von Tuerckheim 1163, US) for the name differs notably from Gilg's original description of $D$. selerorum and its neotype by having inflorescences borne on much longer peduncles (4.5-5 cm vs. 1.7$2 \mathrm{~cm}$ long) with fewer flowers per pistillate inflorescence (25 to 38 vs. ca. 60), and flowers with longer pedicels (ca. $10 \mathrm{~mm}$ vs. 7-8 mm long). Given these differences, both D. malacophylla and D. selerorum are tentatively maintained as species distinct from $D$. radiata.

Daphnopsis utilis Warm., Vidensk. Meddel. Dansk Naturhist. Foren. Kjøbenhavn 1871: 318-320. 1871. TYPE: Brazil. "in vic. Rio de Janeiro, Lagoa Santa, in silvis et virgultis haud rara," s.d., A. F. M. Glaziou 2963 (lectotype, designated by Nevling, 1959: 335, C 10001736; isotype, C 10001735).

Daphnopsis sessiliflora Griseb. ex Taub., Bot. Jahrb. Syst. 12 (Beibl. 27): 8-9. [24 June] 1890. TYPE: Brazil. [Rio de Janeiro, Serra dos Órgãos, 28 Feb. 1889], A. F. M. Glaziou 17747 (lectotype, designated here, G 00190927; possible isotypes, BM 000092158 , C, F not seen, G [specimen stored in same folder jacket as G 00190927], K 000567859, LE, NY 00017525, P, RB 44890, US 00117243).

Taubert (1890) cited a single staminate collection (Glaziou 17747) from an unspecified Brazilian locality in the protologue of Daphnopsis sessiliflora. Taubert's main herbarium at B was lost during World War II (Stafleu \& Cowan, 1986), and none of the examined extant duplicates (BM, C, G, K, LE, NY, P, RB, US) bear his handwriting. Both specimens attached to sheet G 00190927 are staminate and are together designated as the lectotype of $D$. sessiliflora because they are in good physical condition, and the label on the sheet includes the locality mentioned by Glaziou in a publication about his own Brazilian collecting localities (Glaziou, 1913). Within the same folder jacket containing G 00190927, there is another staminate specimen of Glaziou 17747 (no barcode/ accession number) attached to a different sheet, and that specimen is regarded as a possible duplicate of the lectotype.

Daphnopsis zamorensis Domke, Notizbl. Bot. Gart. Berlin-Dahlem 12: 729. [6 Dec.] 1935. Ecuador. Around Zamora and Loja, E Andes, 10001500 m, Nov. [no year], F. C. Lehmann 4823 (lectotype, designated here, K 000567830).

The holotype of Daphnopsis zamorensis deposited at B was destroyed. Nevling (1959), unable to locate extant duplicates, treated the species as one of uncertain status, but Nevling and Barringer (1988) and León-Yánez (1999) have since formally recognized the species. One extant duplicate of Lehmann 4823 has been found at K (K 000567830). The sheet, which was not annotated by Domke, includes two leaves and four pistillate flowering inflorescences that closely match the protologue description. All parts belonging to the sheet are collectively designated as lectotype.

Examination of the type material confirms that Daphnopsis zamorensis is a distinctive species, easily recognized by its ca. $8 \mathrm{~cm}$ long pistillate racemose inflorescences and its relatively large obovate leaves reaching $27 \times 8 \mathrm{~cm}$ in size. Nevling and Barringer (1988) erroneously reported 1-2 mm long petioles for the species in a key to Ecuadorian species; the petioles on the $\mathrm{K}$ lectotype are $1-1.5 \mathrm{~cm}$ long and were described as such in Domke's original 1935 description.

\section{FUNIFERA}

Funifera brasiliensis (Raddi) Mansf., Kulturpflanze, Beih. 2: 299. 1959. Basionym: Daphne brasiliensis Raddi, Mem. Mat. Fis. Soc. Ital. Sci. Modena, Pt. Mem. Fis. 18(2): 391. 1820. TYPE: Brazil. [Rio de Janeiro:] "Trovasi nei Boschi in vic. de Rio-Janeiro, e seg. Presso Matacavallos," s.d., G. Raddi s.n. (lectotype, designated as "type" by Nevling [1965: 235], PI). 
Lagetta funifera Mart. \& Zucc., Flora 7(1) (Beibl. 4): 136. [25 Apr.-30 June] 1824. TYPE: Brazil. Iter Brasil, habitat in sepibus ad Rio de Jo., s.d., C. F. P. von Martius s.n. (lectotype, designated here, M 0146002). EPITYPE: "Tab. 39, Lagetta Funifera," pl. 39 in Martius \& Zuccarini, Nov. Gen. Sp. Pl., Vol. 1. 1824 (epitype, designated here, pl. 39, Martius \& Zuccarini, 1824b).

The protologue of Lagetta funifera consisted of a reference to a plate, numbered 39 , followed by a brief, but diagnostic description based on staminate and pistillate material (Martius \& Zuccarini, 1824a: 136). Plate 39, an illustration of the species in partial color, was actually published several months later on 1 October 1824 in the companion publication Nova Genera et Species Plantarum (Martius \& Zuccarini, 1824b: 65), and in that work, the species received a greatly amplified description followed by the provenance statement, "Habitat locis montanis ad Aquaeductum prope Rio de Janeiro. Floret Julio." Six sheets deposited in the Munich herbarium belong to L. funifera. Five of those sheets (M 01460010146005) were collected by Martius and probably represent original material. Moreover, sheet M 0146002 with an ample staminate specimen and sheet M 0146005 with two pistillate specimens are clearly syntypes as they were both annotated with the species name by Martius. Either sheet would be an equally suitable choice for lectotype and the two were probably source material (i.e., typotypes) for plate 39 (Martius \& Zuccarini, 1824b). The large staminate specimen affixed to M 0146002 is designated as lectotype. Few intact flowers remain on the lectotype, so plate 39 , which includes diagnostic features such as habit, staminate and pistillate flowers, fruits, and seeds, is designated here as the epitype to support the lectotype (Art. 9.7, McNeill et al., 2006). The valid name, Daphne brasiliensis Raddi (1820), appeared as a synonym below Lagetta funifera in the amplified description and plate (Martius \& Zuccarini, 1824b). Raddi's name, however, was not mentioned in the original protologue (Martius \& Zuccarini, 1824a), otherwise Martius' name would have been invalidated.

Funifera ericiflora (Gilg \& Markgr.) Domke, Biblioth. Bot. 27(111): 57. 1934. Basionym: Daphnopsis ericiflora Gilg \& Markgr., Repert. Spec. Nov. Regni Veg. 19: 113. [30 June] 1923. TYPE: Brazil. Matto Grosso: Rio Sacre, June 1909, F. C. Hoehne (Commissão Rondon) 2112 (lectotype, designated here, R 27302).

Gilg and Markgraf used a single staminate Hoehne collection numbered 2112 in the protologue description of Daphnopsis ericiflora (Markgraf, 1923). The holotype deposited at B, Gilg and Markgraf's home institution, was destroyed. An extant duplicate of Hoehne 2112 deposited at R (R 27302) bears an undated typewritten determination of the name by Markgraf. The sole staminate specimen affixed to that sheet is designated as the lectotype. Hoehne (1951) stated that the locality of his number 2112 was Rio Xacuruiná [Sacuruiná or Sucuruiná?] on the side of Ponte de Pedra, but his assertion was probably a mistake since Rio Sacre is clearly noted in the protologue and on the label of the lectotype. Besides the lectotype, Funifera ericiflora may still only be known from two other collections: Hoehne 5504 (R) from Juruena, Mato Grosso (Nevling, 1965), and Pires et al. 6274 (NY) from Serra do Cachimbo, Pará (Rossi, 1997, unpublished).

\section{GOODALLIA}

Goodallia guianensis Benth., London J. Bot. 4: 633634. [Dec.] 1845. TYPE: [Guyana]. British Guiana, near the brook Curassawaka, 1836, $R$. Schomburgk 142 p.p. (lectotype, designated here, $\mathrm{K} 000567821$ [specimen in lower half]; isotypes, BM [2], G 00190984, G 00190985, G 00190986 , G 00190987, G-DC 00130556, K [3], NY 00017523, U 0006867, U 0006868).

Goodallia guianensis Benth. var. parvifolia Benth., London J. Bot. 4: 634. [Dec.] 1845, as "var.? parvifolia," syn. nov. TYPE: [Guyana]. British Guiana, near the brook Curassawaka, 1836, R. Schomburgk 142 p.p. (lectotype, designated here, K 000567821 [specimen in upper half]).

In the protologue of Goodallia Benth., non Goodallia T. E. Bowdich, Bentham (1845: 633-634) published three separate descriptions for the genus, the species $G$. guianensis, and a single variety $G$. guianensis var. parvifolia. For the species, Bentham cited the provenance of the original material as "[o]n the brook Curassawaka, a tributary of the Rupunoony, Schomburgk, 1st Coll. n. 142, in part," whereas for the variety he noted "[s]ent by Schomburgk with the last under the same number [142], and possibly gathered from the same bush, but the foliage and branches are so very different as to leave it doubtful whether they do not belong even to a distinct species." Regarding typification, four sheets labeled Schomburgk 142 were found at K, but only one sheet (K 000567821), with two attached specimens, was annotated with the species name by Bentham. The specimen in the lower half of the sheet corresponds to the protologue description of G. guianensis, and this specimen alone is designated as the lectotype of the species name. The specimen attached to the upper half of that same sheet (K 000567821) is the only original material of $G$. guianensis var. parvifolia and is designated as the 
lectotype of the varietal name. None of the material seen at $\mathrm{K}$ was annotated with the varietal name. Bentham's reported differences of the small-leaved variety were clearly artificial because the specimen he used for the varietal description was collected from a branch growing near the tip of a stem where leaves are usually smaller, narrower, and apiculate at their apices. Alternatively, leaves collected from older branches are generally larger and broader with rounded-obtuse apices as seen on the type material of $G$. guianensis. Long intact branches showing a continuous range of leaf variation for the species are mounted on Ducke 1310 (F, NY, US), Mutchnick 709 (NY), and Ule 7868 (K).

\section{LAGETTA}

Lagetta lagetto (Sw.) Nash, J. New York Bot. Gard. 9: 117. [June] 1908. Basionym: Daphne lagetto Sw., Prodr. (Swartz) 63. [20 June-29 July] 1788. TYPE: Jamaica. "Ind. occid. Jam.," s.d., Herb. O. Swartz s.n. (lectotype, designated here, S S-R-1400).

In the protologue of Daphne lagetto, Swartz (1788: 63) explicitly cited at least three sources of original material by referencing three pre-Linnaean names via the statement, "Lagetto. 10-11. D. spicis paniculatis terminalibus, foliis ovatis acutis. Brown. jam. 371. t. 31. f. 5. Laurifolia arbor. Sloan h. 2. 22. t. 168. 1. 2. 3. 169. I. Bois dentelle. Nicols. Doming. 172. t. 1. f. 1, 2, 3, 4, 5. Jamaica, Hispaniola." The descriptions and accompanying illustrations in all three pre-Linnaean publications probably represent $D$. lagetto and match the morphology of the sole herbarium sheet annotated with that name in Swartz's own herbarium (S-R-1400 at S). That sheet, designated here as lectotype, is fertile and in good condition, and was annotated with the species name by Swartz himself. Nordenstam et al. (1994) noted that Swartz types might also be deposited at BM and SBT, but no original material has been identified at either of those institutions.

\section{LOPHOSTOMA}

Lophostoma ovatum Meisn., Prodr. 14(2): 600. [Nov.] 1857. TYPE: [Brazil. Amazonas: Manáos] "Circa Barra, prov. Rio Negro," May 1851, R. Spruce 1461 (holotype, G-DC 00131539; isotypes, BM $000092160, \mathrm{E} 00313897, \mathrm{G}$ 00190894, K 000567925, K 000567926, K 000567927, LE not seen, NY fragm. 00017519, P 00713268, P 00713269, TCD 0007491).

Linostoma albifolium Barb. Rodr., Vellosia (ed. 2) 1: 67-68. 1891. TYPE: "Est. XX. Linostoma albiflorum [sphalm., albifolium] Barb. Rod.," pl. 20 in Barbosa Rodrigues, Vellosia (ed. 2), 3.1891 (lectotype, designated here, pl. 20, Barbosa Rodrigues, 1891b).
Lophostoma bolleanum Domke, Notizbl. Bot. Gart. BerlinDahlem 11: 350-352. [30 Mar.] 1932. TYPE: Brazil. Civ. Amazonas, Manáos, "silva paludosa et periodice inundabili ad Igarapé do Crespo," 22 July 1929, A. Ducke 23469 (lectotype, designated here, S 09-21081; isotypes, G 00190965, K 000567924, P 00713270, RB 23469, U 0006874, US 00117193).

In the protologue of Linostoma albifolium, Barbosa Rodrigues (1891a: 67-68) cited one collection numbered 63 in the Herb. Museu Botanico do Amazonas series, mentioned the provenance "Hab. in Rio Negro, circa Manaos. Floret m. Januario," and made reference to a related plate numbered 20. All but two Amazonian herbarium collections made by Brazilian botanist João Barbosa Rodrigues (1842-1909) were lost when the Museu Botanico do Amazonas closed in 1890 (Cribb \& Toscano de Brito, 1996). No duplicates of original material of $L$. albifolium have been found despite sending inquiries to several Brazilian herbaria (R, RB, SP, SPF). Plate 20, illustrated by Barbosa Rodrigues and published the same year as the description, represents the only extant original material for the name (Barbosa Rodrigues, 1891b). The plate includes detailed diagnostic illustrations of flowers and fruits and is designated as the lectotype of $L$. albifolium following Articles 9.2 and 9.10 (McNeill et al., 2006). The epithet of the species was spelled albifolium for the description and in the text index (Barbosa Rodrigues, 1891a), but appeared as albiflorum in the caption of plate 20 and in the index for plates (Barbosa Rodrigues, 1891b). There is little doubt that Barbosa Rodrigues intended for the orthography of the epithet to be albifolium, because the terminal leaves in the description were described as white (i.e., glaucous), while the flower color was not specifically mentioned.

The B holotype for Lophostoma bolleanum was destroyed. Several duplicates of the type collection, Ducke 23469, were examined from G, K, P, RB, S, U, and US, but none of those were annotated by Domke. The sole specimen affixed to sheet S 09-21081 is designated as the lectotype of $L$. bolleanum as it is in the best physical condition.

OVIDIA

Ovidia pillopillo (Gay) Meisn., Prodr. 14(2): 524. [Nov.] 1857. Basionym: Daphne pillopillo Gay, Fl. Chil. 5: 315-316. 1849 [published 1851 or 1852 fide Stafleu \& Cowan, 1976]. TYPE: Chile. Valdivia, Feb. 1835, C. Gay 188 (lectotype, designated here, NY 00386220).

Gay (1849) specifically mentioned the locality of Valdivia, Chile, without citing a collection in the protologue of Daphne pillopillo. According to Stafleu 
and Cowan (1976), Gay's herbarium and types are deposited at $\mathrm{P}$, but the original material for the name has not been found despite extensively searching the Thymelaeaceae collections at $\mathrm{P}$ on several occasions between 2003 and 2009. Presumably the holotype has been missing for a long time, since Nevling did not receive any type material on loan from $\mathrm{P}$ for his Ovidia treatment, and he instead only mentioned a duplicate of Gay 188 at NY as an isotype (Nevling, 1964: 78, 80). The label on that NY sheet (00386220) mentions Valdivia and is stamped Herb. Mus. Paris. Three specimens, all matching the protologue description and attached to NY 00386220 , are together designated as the lectotype since the $\mathrm{P}$ holotype is missing.

\section{SCHOENOBIBLUS}

Schoenobiblus coriaceus Domke, Notizbl. Bot. Gart. Berlin-Dahlem 11: 355-356, f. 8 (nos. 24). [30 Mar.] 1932. TYPE: Colombia. [Magdalena:] Santa Marta, Las Nubes, forest hillside, 4500 ft., 5 Dec. 1898-1901, H. H. Smith 795 (lectotype, designated here, G 00191005; isotypes, A 00061578, BM, F 137800, G 00191004, GH 00072383, L 0010249, MO 1786785, NY 00386368, P 00713366, P 00713367, S 04-804, U 0006882, US 00117255).

The holotype of Schoenobiblus coriaceus at B was destroyed, but extant duplicates of Smith 795 were examined from A, BM, F, G, GH, L, MO, NY, P, S, U, and US. Of these sheets, only G 00191004 and G 00191005 were annotated by Domke (det. "co-typus" with the species name and stamped 1935). The single specimen affixed to each $G$ sheet closely matches the description and the associated floral illustrations published in the protologue. Sheet G 00191005 includes a slightly more complete specimen and is therefore designated as lectotype. Schoenobiblus coriaceus is provisionally recognized as a distinct species, but the genus, with its 11 published species names, is in need of taxonomic revision.

Schoenobiblus daphnoides Mart., Nov. Gen. Sp. Pl. 1(3): 65. 1824. TYPE: Brazil. "Brasilia Provinc. do Alto Amazonas, in sylvis inundatis ad fluv. Japurá," s.d., C. F. P. von Martius s.n. (lectotype, designated here, M 0146089).

Schoenobiblus and its type $S$. daphnoides were validly published simultaneously via a single description (descriptio generico-specifica) in accordance with Article 42.1 (McNeill et al., 2006). In the protologue (Martius \& Zuccarini, 1824b: 65), Martius provided a brief Latin description for the genus including a few staminate floral characters, followed by the provenance "Habitat in sylvis inundatis ad flumen Japurá, Provinciae a flumine nigro dictae." There are three specimens in the Munich herbarium (M 01460870146089) matching the description and provenance mentioned in the protologue, but none bear inscriptions of the species name in Martius' handwriting. Sheet M 0146089, designated here as the lectotype of S. daphnoides, has the most intact open flowers of any sheet and was probably used later for the detailed illustration that accompanied the amplified description appearing in Flora Brasiliensis (Meisner, 1855). The two other sheets at M (M 0146087 and M 0146088) are regarded as syntypes.

Schoenobiblus ellipticus Pilg., Verh. Bot. Vereins Prov. Brandenburg 47(2): 162-163. [1 Oct.] 1905. TYPE: Brazil. Amazonas: Rio Juruá, Marary [Marari], Oct. 1900, E. Ule 5253 (lectotype, designated here, G 00191003 [O* fls.]; isotypes, K 000567876 [ơ fls., upper half of sheet], L 0043234 [O' fls., upper half of sheet]).

In the protologue of the dioecious Schoenobiblus ellipticus, Pilger (1905: 162) used pistillate and staminate plants mixed under the same collection number (Ule 5253) for his description. The original material deposited at B was destroyed, but extant duplicates have been examined from $\mathrm{G}, \mathrm{K}$, and L. Two sheets of Ule 5253 are at G. The first G sheet bears barcode information (G 00191003), a label with a detailed locality, and a staminate specimen, whereas the second $G$ sheet, mounted within the same folder jacket as G 00191003, lacks a barcode and locality, and bears a pistillate specimen. The staminate specimen explicitly barcoded G 00191003 is designated here as the lectotype of $S$. ellipticus, while the staminate specimens affixed to the upper half of $\mathrm{L}$ 0043234 and K 000567876 are treated as duplicates of the lectotype. The sheet with the pistillate flowering specimen jacketed with G 00191003 and the pistillate material attached to the lower half of sheets $\mathrm{L}$ 0043234 and K 000567876 are all regarded as syntypes.

Schoenobiblus peruvianus Standl., Field Mus. Nat. Hist., Bot. Ser. 11(5): 169. [10 Feb.] 1936. TYPE: Peru. Dept. Loreto, Timbuchi on the Río Nanay, 1 July 1929 (ơ fls.), L. Williams 1162 (lectotype, designated here, F 608105; isotype, G 00191002).

Standley (1936: 169) cited five Peruvian syntypes in the protologue of Schoenobiblus peruvianus as "Peru: Timbuchi, Alto Río Nanay, Dept. Loreto, July 
1, 1929, Llewelyn Williams 1162. Paraíso, Alto Itaya, Williams 3354. Pebas, in forest, Williams 1707, 1878, 1595." The sheet of Williams 1162 deposited at F (608105) is in staminate flower, bears Standley's own handwritten annotation as type, and is designated as the lectotype of $S$. peruvianus. The four other syntypes are fruiting. Schoenobiblus peruvianus has been recognized as a distinct species for Peru (Macbride, 1941; Zarucchi, 1993; Vásquez Martínez, 1997) and Ecuador (León-Yánez, 1999), and the species is provisionally accepted here pending further taxonomic investigation.

Acknowledgments. The author graciously thanks the following people and institutions for their assistance with various aspects of this research: Ruy José Válka Alves (R), Lucia Amadei (PI), Arne Anderberg (S), Cécile Aupic (P), Gérard Aymonin (P), Y. Baksh-Comeau (TRIN), Gloria Barboza (CORD), Helen Barnes (MEL), Christian Braeuchler (M), Patrick Bungener (G), Andrew Doran (UC), Sara Edwards (K), Luis Ariza Espinar (CORD), HansJoachim Esser (M), Brian Franzone (GH), Nicolas Fumeaux (G), Laurent Gautier (G), Jochen Heinrichs (GOET), John Hunnex (BM), Jean-Nöel Labat (P), Paula Leitman (RB), Caroline Loup (P), Maria Candida Henrique Mamede (SP), Vera Martins (R), Pina Milne (MEL), Anne Morley-Smith (K), Christine Niezgoda (F), Néstor Pérez-Molière (NY), José Rubens Pirani (SPF), Hans-Helmut Poppendieck (HBG), P. Kim Roberts (TRIN), Olof Ryding (C), Adele Smith (E), James Solomon (MO), Monika Steinhof (BREM), Mary Stiffler (MO), D. Stella Sylva (NY), Barbara Thiers (NY), Helen Townsend (E), Alison Vaughan (MEL), Robert Vogt (B), Emily Wood (A and GH), and Gea Zijlstra (U). I am especially grateful to Lúcia Rossi (SP) for providing helpful unpublished data and review comments, Maria Lúcia Kawasaki (F) and Stephan Beck (LPB) for reviewing the manuscript, Victoria Hollowell (MO) for editorial assistance, Johannes Lundberg (S) and Thomas Zanoni (NY) for data entry, Nicholas Turland (MO) for guidance regarding a few particularly challenging nomenclatural issues, Joe Ditto (MO) for his computer programming expertise, and Benjamin Torke (NY) and Lupita Sánchez-Torke for showing me warm hospitality during my visit to NY.

\section{Literature Cited}

ABG. 2010. Auxilium ad botanicorum graphicem [online version]. Conservatoire et Jardin Botaniques Ville de Genève website, <http://www.ville-ge.ch/musinfo/bd/cjb/ auxilium/index.php $>$, accessed 16 September 2010.

Adanson, M. 1763. Familles des Plantes, Vol. 2. Vincent, Paris.
Barbosa Rodrigues, J. 1891a. Thymelaeaceae, Linostoma albifolium. Vellosia, ed. 2, 1: 67-68.

- 1891b. Linostoma albiflorum $[=$ albifolium $]$. Vellosia, ed. 2, 3: plate 20.

Barringer, K. \& J. F. Pruski. 2005. Two new cauliflorous species of Daphnopsis (Thymelaeaceae) from French Guiana and Surinam. Novon 15: 50-54.

\& L. I. Nevling Jr. 1987. New species of Schoenobiblus (Thymelaeaceae) from Venezuela. Brittonia 39: 428-431.

Bentham, G. 1845. Contributions towards a flora of South America: Enumeration of plants collected by Sir Robert Schomburgk, in British Guiana. London J. Bot. 4: 622634.

1846. Plantas Hartwegianus. W. Pamplin, London.

Berry, P. E. \& Z. S. Rogers. 2005. Tepuianthaceae. Pp. 297-299 in P. E. Berry, K. Yatskievych \& B. K. Holst (editors), Flora of the Venezuelan Guayana, Vol. 9 (Rutaceae-Zygophyllaceae). Missouri Botanical Garden Press, St. Louis.

— \& J. A. Steyermark. 2007. Thymelaeaceae. P. 537 in V. Funk, T. Hollowell, P. Berry, C. Kelloff \& S. N. Alexander (editors), Checklist of the Plants of the Guiana Shield (Venezuela: Amazonas, Bolivar, Delta Amacuro; Guyana, Surinam, French Guiana). Contr. U.S. Natl. Herb., Vol. 55. Department of Botany, National Museum of Natural History, Washington, D.C.

Borhidi, A. \& O. Muñiz. 1976 [1977]. Plantas nuevas en Cuba V. Acta Bot. Acad. Sci. Hung. 22: 295-320.

Bowdich, T. E. 1825. Excursions in Madeira and Porto Santo, during the Autumn of 1823, while on his Third Voyage to Africa. George B. Whittaker, London.

Cribb, P. \& A. L. Toscano de Brito. 1996. Introduction and history. Pp. 23-32 in S. Sprunger (editor), Iconographie des orchidées du Brésil/João Barbosa Rodrigues, Vol. 1: Illustrations. Friedrich Reinhart Verlag, Basel, Switzerland.

Cronquist, A. 1968. The Evolution and Classification of Flowering Plants. Houghton Mifflin, Boston.

Cuatrecasas, J. 1962. Studies in South American plants-VI. Brittonia 14: 50-57.

Domke, W. 1935. Neue Arten und Varietäten der Gattungen Daphnopsis Mart. et Zucc. und Funifera (Leandro ex) C. A. Mey. aus Mittel- und Südamerika. Notizbl. Bot. Gart. Berlin-Dahlem 12: 722-732.

Donnell Smith, J. 1889. Daphnopsis radiata. Bot. Gaz. 14: 30. Floden, A. J., M. H. Mayfield \& C. J. Ferguson. 2009. A new narrowly endemic species of Dirca (Thymelaeaceae) from Kansas and Arkansas, with a phylogenetic overview and taxonomic synopsis of the genus. J. Bot. Res. Inst. Texas 3: 485-499.

Gay, C. 1849. Historia Fisica y Politica de Chile, Vol. 5. E. Thunot, Paris.

Gilg, E. 1917. Thymelaeaceae. P. 153 in L. E. T. Loesener, Plantae Selerianae IX. Verh. Bot. Vereins Prov. Brandenburg 58: 129-324.

Glaziou, A. F. M. 1913. Plantae Brasiliae centralis a Glaziou lectae, liste des plantes du Brésil Central recueillies en 1861-1895. Mem. Soc. Bot. France 1(3): 1-661.

Grisebach, A. 1879. Symbolae ad Floram Argentinam. Dieterich, Göttingen.

Heads, M. J. 1990. A revision of the genera Kelleria and Drapetes (Thymelaeaceae). Austral. Syst. Bot. 3: 595-652.

Herber, B. E. 2003. Thymelaeaceae. Pp. 373-396 in K. Kubitzki (editor), The Families and Genera of Vascular Plants, Vol. 5: Flowering Plants. Dicotyledons. Malvales, Capparales and Non-betalain Caryophyllales. Springer, Berlin. 
Hoehne, F. C. 1951. Índice Bibliográfico e Numérico das Plantas Colhidas pela Comissão Rondon. Instituto de Botânica, São Paulo.

Horn, J. W. 2004. The morphology and relationships of the Sphaerosepalaceae (Malvales). Bot. J. Linn. Soc. 144: $1-40$.

Hunziker, A. T. 1960. Catalogo de los tipos "Grisebachianos" conservados en Cordoba, estudio critico del material de tipos de nomenclatura de las especies y variedades descriptas por Grisebach en "Plantae Lorentzianae" y "Symbolae ad Floram Argentinam", existentes en el Museo Botanico de Cordoba. Trab. Mus. Bot. Córdoba 2: 283-421.

Jussieu, A. L. de. 1789. Genera Plantarum. Viduam Herissant \& Theophilum Barrois, Paris.

Kawasaki, M. L. \& S. A. Mori. 2002. Thymelaeaceae (Mezereum Family). Pp. 711-712 in S. A. Mori, G. Cremers, C. A. Gracie, J.-J. de Granville, S. V. Heald, M. Hoff \& J. D. Mitchell (editors), Guide to the Vascular Plants of Central French Guiana, Part 2, Dicotyledons. Mem. New York Bot. Gard., Vol. 76, Pt. 2. New York Botanical Garden Press, Bronx.

Kunth, K. S. 1817. Thymelaeae. Pp. 150-151 in F. W. H. A. von Humboldt, A. J. A. Bonpland \& K. S. Kunth (editors), Nova Genera et Species Plantarum (quarto ed.), Vol. 2. Librariae Graeco-Latino-Germanicae, Paris.

- 1822. Synopsis Plantarum, Vol. 1. F. G. Levrault, Paris.

Laclette, P. P. H. 1977. Sobre uma nova espécie de Thymelaeaceae Daphnopsis aemygdioi P. Laclette. Bol. Mus. Nac. Rio de Janeiro, Bot. 46: 1-15.

Lamarck, J. B. A. P. de M. 1792. Encyclopédie Méthodique. Botanique, Vol. 3. Panckoucke, Paris; Plomteux, Liège.

León-Yánez, S. 1999. Thymelaeaceae. Pp. 925-926 in P. M. Jørgensen \& S. León-Yánez (editors), Catalogue of the Vascular Plants of Ecuador. Monogr. Syst. Bot. Missouri Bot. Gard. 75.

Liogier, A. H. 1982. La Flora de la Española, Vol. 1, Centenario de San Pedro de Macorís, Vol. 6. Universidad Central del Este, San Pedro de Macorís, Dominican Republic.

Macbride, J. F. 1941. Flora of Peru. Publ. Field Mus. Nat. Hist., Bot. Ser., Vol. 13, Pt. 4, no. 1 (publication 496). Field Museum of Natural History, Chicago.

Maguire, B. \& J. A. Steyermark. 1981. The Botany of the Guyana Highland-Part XI. Mem. New York Bot. Gard., Vol. 32. New York Botanical Garden Press, Bronx.

Markgraf, F. 1923. Eine neue brasilianische Thymelaeacee (Daphnopsis ericiflora). Repert. Spec. Nov. Regni Veg. 19: 113.

Martius, C. F. P. de. \& J. G. Zuccarini. 1824a. Ankündigung der Fortsetzung eines Werkes über brasilianische Pflanzen. Flora 7(1) (Beibl. 4): 129-142.

\& 1 1824b. Nova Genera et Species Plantarum, Vol. 1. Typis Lindaueri, Munich.

McNeill, J., F. R. Barrie, H. M. Burdet, V. Demoulin, D. L. Hawksworth, K. Marhold, D. H. Nicolson, J. Prado, P. C. Silva, J. E. Skog, J. H. Wiersema \& N. J. Turland (editors). 2006. International Code of Botanical Nomenclature (Vienna Code). Regnum Veg. 146.

Meisner, C. F. 1855. Thymelaeaceae. Pp. 61-72 in C. F. P. de Martius (editor), Flora Brasiliensis, Vol. 5, Pt. 1. F. Fleischer, Munich.

- 1857. Thymelaeaceae. Pp. 493-605 in A. L. P. P. de Candolle (editor), Prodromus Systematis Naturalis Regni Vegetabilis, Vol. 14, Pt. 2. Victoris Masson, Paris.
Meyer, C. A. 1843. Bemerkungen über die Gattungen der Daphnaceen. Bull. Cl. Phys.-Math. Acad. Imp. Sci. SaintPétersbourg [sér. 2], 1: 353-359.

Nesom, G. L. \& M. H. Mayfield. 1995. A new species of Dirca (Thymelaeaceae) from the sierra of northeastern Mexico. Sida 16: 459-467.

Nevling Jr., L. I. 1959 [1960]. A revision of the genus Daphnopsis. Ann. Missouri Bot. Gard. 46: 257358.

- 1960. Nomenclatural changes in Daphnopsis. J. Arnold Arbor. 41: 412-413.

- 1963a. A revision of the genus Lophostoma (Thymelaeaceae). J. Arnold Arbor. 44: 143-164.

. 1963b. Notes on Daphnopsis. J. Arnold Arbor. 44: $402-410$. $72-86$.

1965. A preliminary report on Funifera. J. Arnold Arbor. 46: 232-241.

- 1976. A new species of Funifera (Thymelaeaceae). Phytologia 32: 480-482.

\& P. Raulino Reitz. 1968. Timeleáceas. Pp. 1-21 in P. Raulino Reitz (editor), Flora Ilustrada Catarinense, Vol. 1. Herbário Barbosa Rodrigues, Itajaí, Santa Catarina, Brazil.

- \& K. Barringer. 1986. New and noteworthy species of Daphnopsis (Thymelaeaceae) from Mexico and Central America. Phytologia 61: 361-366.

— - 1988. A new and endangered species of Daphnopsis (Thymelaeaceae) from Ecuador. Ann. Missouri Bot. Gard. 75: 728-729.

Noa Monzón, A. 1992 [1995]. Nuevo tratamiento de la familia Thymelaeaceae Jussieu en Cuba. Revista Jard. Bot. Nac. Univ. Habana 13: 39-43.

2009. Thymelaeaceae. Pp. 1-39 in W. Greuter \& R. Rankin Rodríguez (editors), Flora de la República de Cuba, fascicle 15(13). Koeltz Scientific Books, Koenigstein.

Nordenstam, B., R. Lundin \& T. A. Zanoni. 1994. Herbaria of Olof Swartz and Erik L. Ekman at Stockholm (S). Flora of the Greater Antilles Newsletter 5: 2-4.

Nordmann, A. von. 1837. Vorlaufige diagnosen einiger während einer naturwissenschaftlichen Reise im westlichen theile der Kaukasischen provinzen entdeckten und als neu erkannten Pflanzenspecies. Bull. Sci. Acad. Imp. Sci. Saint-Pétersbourg 2: 311-314.

Philcox, D. 1978. Thymelaeaceae. Pp. 592-594 in Flora of Trinidad and Tobago, Vol. 2, Pt. 9. Government Printery, Ministry of Agriculture, Lands and Fisheries, Port-ofSpain, Trinidad.

Pilger, R. 1905. Beiträge zur Flora der Hylaea nach den Sammlungen von E. Ule. Verh. Bot. Vereins Prov. Brandenburg 47: 100-191.

Plowman, T. \& L. I. Nevling Jr. 1986. A new species of Lasiadenia (Thymelaeaceae) from Venezuela. Brittonia 38: 114-118.

Raddi, G. 1820. Quaranta piante nuove del Brasile raccolte e descritte da Giuseppe Raddi. Mem. Mat. Fis. Soc. Ital. Sci. Modena, Pt. Mem. Fis. 18: 382-414.

Rafinesque, C. S. 1838. Flora Telluriana, Vol. 4. H. Probasco, Philadelphia.

Rogers, Z. S. \& M. A. Spencer. 2006. Typification of plants names in Thymelaeaceae published by Linnaeus and Linnaeus filius. Taxon 55: 483-488.

- C. Antezana, J. R. I. Wood \& S. G. Beck. 2004. A distinctive new species of Ovidia (Thymelaeaceae) from Bolivia. Novon 14: 332-336. 
, P. E. Berry \& J. A. Steyermark. 2005. Thymelaeaceae. Pp. 332-342 in P. E. Berry, K. Yatskievych \& B. K. Holst (editors), Flora of the Venezuelan Guayana, Vol. 9 (Rutaceae-Zygophyllaceae). Missouri Botanical Garden Press, St. Louis.

Rossi, L. 1997. Revisão Taxonômica das Espécies da Família Thymelaeaceae do Brasil. Ph.D. Thesis, Universidade de São Paulo, São Paulo.

Stafleu, F. A. \& R. S. Cowan. 1976. Taxonomic Literature, ed. 2, Vol. 1: A-G. Bohn, Scheltema \& Holkema, Utrecht. \& \& - 1979. Taxonomic Literature, ed. 2, Vol. 2: H-Le. Bohn, Scheltema \& Holkema, Utrecht. Sti-Vuy. Bohn, Scheltema \& Holkema, Utrecht.
. 1986. Taxonomic Literature, ed. 2, Vol. 6 :

\& 1 . 1988. Taxonomic Literature, ed. 2, Vol. 7: W-Z. Bohn, Scheltema \& Holkema, Utrecht.

Standley, P. C. 1936. Studies of American plants-VI. Publ. Field Mus. Nat. Hist., Bot. Ser. 11: 145-276.

\& L. O. Williams. 1962. Flora of Guatemala.

Fieldiana, Bot., Vol. 24, Pt. 7, no. 2. Chicago Natural History Museum Press, Chicago.

Steinberg, C. H. 1977. The collectors and collections in the Herbarium Webb. Webbia 32: 1-49.

Steyermark, J. A. 1986-1987 [1987]. Notes on the flora of Serra Aracá. Acta Amazon. 16-17: 219-222.

. 1987. Flora of the Venezuelan Guayana-III. Ann. Missouri Bot. Gard. 74: 609-658.

Swartz, O. 1788. Nova Genera \& Species Plantarum. In Bibliopoliis Acad. M. Swederi, Stockholm, Uppsala \& Abo [Turku, Finland].

Swedish Museum of Natural History. 2010. Handwriting: Linnean herbarium (S-LINN). Swedish Museum of Natural History website, < http://linnaeus.nrm.se/botany/fbo/hand/ welcome.html.en>, accessed 18 May 2010.
Taubert, P. 1890. Plantae Glaziovianae novae vel minus cognitae. Bot. Jahrb. Syst. 12(Beibl. 27): 1-20.

Tropicos. 2010. Tropicos.org database. Missouri Botanical Garden, <http://tropicos.org/>, accessed 28 October 2010.

Turland, N. J. \& C. E. Jarvis (editors). 1997. Typification of Linnaean specific and varietal names in the Leguminosae (Fabaceae). Taxon 46: 457-485.

Ule, E. 1914. Die vegetation des Roraima. Bot. Jahrb. Syst. 52(Beibl. 115): 42-53.

Urban, I. 1892. Additamenta ad cognitionem florae Indiae occidentalis, particula I. Bot. Jahrb. Syst. 15: 286-361.

Vásquez Martínez, R. 1997. Thymelaeaceae. Pp. 707-708 in A. Rudas Lleras \& C. M. Taylor (editors), Flórula de las Reservas Biológicas de Iquitos, Perú. Monogr. Syst. Bot. Missouri Bot. Gard. 63.

Vellozo, J. M. da C. 1825 [1829]. Florae Fluminensis. Typographia Nationali, Rio de Janeiro.

—. 1827 [1831]. Florae Fluminensis [Icones], Vol. 4. Senefelder, Paris.

Wikström, J. E. 1817a. Dissertatio de Daphne [dissertation]. H.A.M.S., Zeipel \& Palmblad, Uppsala.

. 1817b. Dissertatio de Daphne [commercial edition]. H.A.M.S., Uppsala. 1820. Dissertatio de Daphne... (editio altera, emendata et aucta). A. M. Strinnholm, Stockholm.

Wurdack, K. J. \& J. W. Horn. 2001. A reevaluation of the affinities of the Tepuianthaceae: Molecular and morphological evidence for placement in Malvales [abstract]. Botany 2001 Abstracts: 151.

Zarucchi, J. L. 1993. Thymelaeaceae. Pp. 1147-1148 in L. Brako \& J. L. Zarucchi (editors), Catalogue of the Flowering Plants and Gymnosperms of Peru. Monogr. Syst. Bot. Missouri Bot. Gard. 45. 


\section{$2 \mathrm{BHL}$ Biodiversity Heritage Library}

Rogers, Zachary S. 2010. "Nomenclatural Notes on American

Thymelaeaceae." Novon a journal of botanical nomenclature from the Missouri Botanical Garden 20, 448-462.

View This Item Online: https://www.biodiversitylibrary.org/item/123332

Permalink: https://www.biodiversitylibrary.org/partpdf/122057.

\section{Holding Institution}

Missouri Botanical Garden, Peter H. Raven Library

\section{Sponsored by}

Missouri Botanical Garden

\section{Copyright \& Reuse}

Copyright Status: Permission to digitize granted by rights holder Rights: https://www.biodiversitylibrary.org/permissions

This document was created from content at the Biodiversity Heritage Library, the world's largest open access digital library for biodiversity literature and archives. Visit BHL at https://www.biodiversitylibrary.org. 